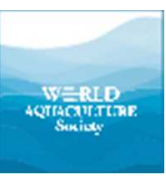

\title{
Effects of deoxynivalenol exposure time and contamination levels on rainbow trout
}

\begin{tabular}{|r|l|}
\hline Journal: & Journal of the World Aquaculture Society \\
\hline Manuscript ID & JWAS-18-032.R3 \\
\hline Manuscript Type: & Applied Studies \\
\hline Date Submitted by the Author: & 24-May-2018 \\
\hline Lomplete List of Authors: & $\begin{array}{l}\text { Goncalves, Rui Alexandre; BIOMIN Holding GmbH; University of Stirling, } \\
\text { Institute of Aquaculture } \\
\text { Menanteau-Ledouble, Simon; University of Veterinary Medicine, Clinical } \\
\text { Division of Fish Medicine } \\
\text { Schöller, Mélanie; University of Veterinary Medicine, Clinical Division of } \\
\text { Fish Medicine } \\
\text { Eder, Alexander; University of Veterinary Medicine, Clinical Division of Fish } \\
\text { Medicine } \\
\text { Schmidt-Posthaus, Heike; University of Bern, Centre for Fish and Wildlife } \\
\text { Health, Department for Infectious Diseases and Pathobiology, } \\
\text { Mackenzie, Simon; University of Stirling, Institute of Aquaculture } \\
\text { El-Matbouli, Mansour ; University of Veterinary Medicine, Clinical Division } \\
\text { of Fish Medicine }\end{array}$ \\
\hline Keywords: & $\begin{array}{l}\text { Mycotoxins, Oncorhynchus mykiss, pathogen susceptibility, hepatocytes } \\
\text { hyalinization }\end{array}$ \\
\hline \hline
\end{tabular}

\section{SCHOLARONE ${ }^{\text {m }}$ \\ Manuscripts}

This is the peer reviewed version of the following article: Gonçalves RA, Menanteau-Ledouble S, Schöller M, et al. Effects of deoxynivalenol exposure time and contamination levels on rainbow trout. Journal of the World Aquaculture Society 2019;50:137154, which has been published in final form at https://doi.org/10.1111/jwas.12542. This article may be used for non-commercial purposes in accordance with Wiley Terms and Conditions for self-archiving. 


\section{Effects of deoxynivalenol exposure time and contamination levels on}

2

3

4

5

$6 \quad{ }^{1}$ BIOMIN Holding GmbH, Erber Campus 1, 3131 Getzersdorf, Austria

$7 \quad{ }^{2}$ Clinical Division of Fish Medicine, University of Veterinary Medicine, Vienna, Austria

$8{ }^{3}$ Centre for Fish and Wildlife Health, Department for Infectious Diseases and Pathobiology,

$9 \quad$ University of Bern, Switzerland

10

11

12

13

14

15

16

17

${ }^{4}$ University of Stirling, Institute of Aquaculture, Stirling, United Kingdom

*Corresponding author: Email: rui.goncalves@,biomin.net

Running title: Effects of deoxynivalenol on rainbow trout

\begin{abstract}
The trend towards using plant-based ingredients in aquafeeds is set to intensify; however, mycotoxin contamination might be a challenge. Two diets, with deoxynivalenol (DON) levels of $1,166 \mu \mathrm{gg}^{-1}(1.1 \mathrm{DON})$ and $2,745 \mu \mathrm{g} \mathrm{kg}^{-1}(2.7 \mathrm{DON})$, were prepared for short-term DON-exposure (50 days). A third diet with a low DON level of $367 \mu \mathrm{g} \mathrm{kg}^{-1}$ (0.3 DON) was prepared for long-term DON-exposure (168 days). Ingestion of DON by trout during both short-term/high-dosage exposure (50 days; $1,166 \mu \mathrm{g} \mathrm{kg}{ }^{-1}$ and $2,700 \mu \mathrm{g}$ $\mathrm{kg}^{-1} \mathrm{DON}$ ) and long-term/low-dosage exposure (168 days; $\left.367 \mu \mathrm{g} \mathrm{kg}^{-1} \mathrm{DON}\right)$ impacted growth performance and, to a lesser extent, liver enzyme parameters (2.7 DON). Histopathology showed mild to moderate changes in the liver but not in the other
\end{abstract}


sampled tissues (intestine and kidney). Despite these effects, short-term exposure of rainbow trout to high doses of DON did not result in increased susceptibility to Yersinia ruckeri. In both the short- and long-term studies, the effects of DON showed a high inter-individual variability. The present study confirms that sub-clinical levels of mycotoxins affect rainbow trout. The effects of such low mycotoxin levels could be masked by other production challenges while still negatively affecting productivity.

Keywords: Mycotoxins, Oncorhynchus mykiss, pathogen susceptibility, hepatocytes hyalinization

\section{Introduction}

In aquaculture, the trend to replace expensive animal-derived proteins, such as fishmeal, with more economical and sustainable plant protein sources has increased the probability of mycotoxin contamination in aquaculture feeds. According to Tacon et al. (2011), plant-based ingredients already represent the major dietary protein source used in feeds for lower trophic level fish species, such as tilapia, carp and catfish. These ingredients also account for the second major source of dietary protein and lipids after fishmeal and fish oil in the feed of shrimp and high trophic level fish species. Various plant sources have been used for salmonids but at lower inclusion levels than feed destined for lower trophic species. In most aquaculture species, plant protein choice and selection are based on a combination of local market availability, cost and the nutritional profile (including anti-nutrient content and level) of the plant meal in question (Gatlin et al., 2007; Davis and Sookying, 2009; Krogdahl et al., 2010). 
51 The mycotoxin contamination of finished feeds and raw materials used in aquaculture as well 52 as the negative effects of mycotoxins on aquatic species, particularly rainbow trout 53 (Oncorhynchus mykiss), has been highlighted in recent publications (Hooft et al., 2011; 54 Ryerse et al., 2015; Tola et al., 2015; Gonçalves et al., 2018; Hooft and Bureau, 2017).

58 Few studies are currently available concerning mycotoxin occurrence in aquaculture plant 59 meals and finished feeds. Gonçalves et al. (2016) reported that deoxynivalenol (DON) was 60 present in $68 \%$ of analyzed samples (shrimp and fish, sampled in Asia and Europe in 2014) at recently, Gonçalves et al. (2018) observed that contamination patterns for shrimp and fish feeds were slightly different, which likely reflects the type of commodity used for the different species. The authors observed that shrimp feeds were generally contaminated with 65 low levels of DON, with the exception of some diets (contamination ranging from $329 \mu \mathrm{g} \mathrm{kg}^{-1}$ to $2,287 \mu \mathrm{g} \mathrm{kg}^{-1}$ of DON). In the case of fish feeds, samples were contaminated mainly by 67 DON, up to a maximum level of $396 \mu \mathrm{g} \mathrm{kg}^{-1}$, and were co-contaminated with other mycotoxins.

Trichothecenes are extremely potent inhibitors of eukaryotic protein synthesis, interfering with the initiation, elongation, and termination stages of this process (Kumar et al., 2013). Knowledge of the effects of DON on aquatic species has increased recently (Hooft et al., 2011; Matejova et al., 2015; Ryerse et al., 2015; Tola et al., 2015; Hooft and Bureau, 2017; Gonçalves et al., 2018), and studies on rainbow trout suggest that DON has a detrimental effect on feed intake, weight gain and feed efficiency (Hooft et al., 2011; Ryerse et al., 2015). (Matejova et al., 2015; Matejova et al., 2017; Ryerse et al., 2015). 
77 In general, the effects of mycotoxicoses vary greatly depending on a variety of factors,

78 including nutritional and health status prior to exposure, dose and duration of exposure, age,

79

80

81

82 species and infection route. In addition, the lack of reliable clinical signs or parameters (including biomarkers) to correctly diagnose the ingestion of DON by aquatic species makes mycotoxin risk management in aquaculture very challenging.

The aim of the present study was to evaluate the effect of DON on rainbow trout under two different scenarios: first, the effect of short-term feeding of high levels of DON (50 days; $1,166 \mu \mathrm{g} \mathrm{kg}^{-1} \mathrm{DON}$ and 2,745 $\left.\mu \mathrm{g} \mathrm{kg}^{-1} \mathrm{DON}\right)$, and second, the effects of long-term feeding of low levels of DON (168 days; $\left.367 \mu \mathrm{g} \mathrm{kg}^{-1} \mathrm{DON}\right)$. Moreover, we aimed to investigate the manifestation of clinical signs due to the ingestion of DON by inspecting several organs and tissues normally affected by the consumption of mycotoxins.

\section{Materials and methods}

Experimental diets

The experimental diets were formulated to be isoenergetic $\left(22.20 \mathrm{~kJ} \mathrm{~g}^{-1}\right.$ dry matter (DM), isoproteic $(52.20 \% \mathrm{DM})$ and isolipidic $(17.90 \% \mathrm{DM})$ (Table 1)). All diets were formulated with the same ingredients. Marine-derived ingredients (fishmeal and fish oil) represented $22.45 \% \mathrm{DM}$ of the diet, whereas plant raw materials represented $59.70 \% \mathrm{DM}$ of the diet. All ingredients were finely ground (hammer mill, 0.8-mm sieve), mixed, and then extruded (twin screw extruder, 2.0-mm pellet size, SPAROS, Portugal).

The ingredients used to formulate the diets were subjected to Liquid chromatography-tandem mass spectrometry, HPLC-MS/MS-based multi-mycotoxin analysis (University of Natural Resources and Life Sciences, Center for Analytical Chemistry Department IFA, Austria), as described by Streit et al. (2013). The method covered major type A and B trichothecenes, zearalenone, fumonisins, aflatoxins and ochratoxins. For the purpose of data analysis, nondetect levels were based on the limits of detection (LOD) of the method used for analysis. The 
103 detected concentrations of major mycotoxins and of a selection of other fungal metabolites are 104 listed in Table 2.

105 Diets with three different levels of DON were prepared by adding DON (Romer Labs 106 Diagnostic GmbH, Austria) to the feed during diet ingredient mixing. Two diets, with DON 107 levels of $1,166 \mu \mathrm{g} \mathrm{kg}^{-1}(1.1 \mathrm{DON})$ and $2,745 \mu \mathrm{g} \mathrm{kg}^{-1}$ (2.7 DON), were prepared for short-term 108 DON exposure (50 days). A third diet with a low DON level of $367 \mu \mathrm{g} \mathrm{kg}^{-1}$ (0.3 DON) was 109 prepared for long-term DON exposure (168 days). All diets were dried at $45 \mathrm{C}$ for 12 hours 110 after the addition of DON and were stored at $4 \mathrm{C}$ until use.

111 Contamination levels were chosen taking into account previous literature on the effect of 112 DON on rainbow trout (Hooft, Elmor et al., 2011; Matejova et al., 2014; Matejova, Vicenova 113 et al., 2015; Ryerse, Hooft et al., 2015) as well as the reported DON levels in worldwide 114 finished feed samples (Gonçalves et al., 2016, 2017, 2018; Greco et al., 2015; Barbosa et al., 115 2013). The long-term exposure to DON attempts to mimic the most recently reported levels of 116 DON in finished feeds (Gonçalves et al., 2018, average of $82.87 \mu \mathrm{g} \mathrm{kg}^{-1}$ and maximum of 396 $117 \mu \mathrm{g} \mathrm{kg}^{-1}$ ). However, the authors are aware that reports of mycotoxin occurrence in European 118 aquaculture finished feeds are still very limited, and levels reported may vary annually (e.g., 119 average DON contamination of $160.86 \mu \mathrm{g} \mathrm{kg}^{-1}$ in 2014 , of $165.61 \mu \mathrm{g} \mathrm{kg}^{-1}$ in 2015 , and of $12087.87 \mathrm{~m} \mathrm{~kg}^{-1}$ in 2016; Gonçalves et al., 2016, 2017 and 2018). Generally, Asian aquafeed 121 samples present higher DON levels compared with European aquafeed samples.

122

\section{Fish and experimental conditions}

This study was approved by the institutional ethics committee and the national authority according to $\S 26$ of Law for Animal Experiments, Tierversuchsgesetz 2016-TVG 2012 under No. BMWFW- 68.205/0135-WF/V/3b/2014. Rainbow trout (Oncorhynchus mykiss) originating from a farm with no prior history of Yersiniosis was used in both experiments. On arrival, the kidneys of ten fish were sampled, and their infection-free status was confirmed by 
129 culture-based analysis and polymerase chain reaction (PCR)-based analysis using Yersinia 130 ruckeri specific primers (del Cerro et al., 2002).

132 For the experiment with short-term exposure to DON, 180 fish $(14.10 \pm 0.05 \mathrm{~g})$ were 133 randomly allocated to three feeding groups in quadruplicate and given either standard feed 134 (control, CTRL), feed contaminated with $1,166 \mu \mathrm{g} \mathrm{kg}^{-1} \mathrm{DON}(1.1 \mathrm{DON})$ or feed contaminated 135 with $2,745 \mu \mathrm{g} \mathrm{kg}^{-1} \mathrm{DON}$ (2.7 DON). Each aquarium of $85 \mathrm{~L}$ was supplied by a flow-through 136 system with a temperature of $15.47 \pm 0.14 \mathrm{C}$, oxygen concentration of $8.73 \pm 0.12 \mathrm{mg} \mathrm{L}^{-1}$, and $137 \mathrm{pH}$ of $7.53 \pm 0.04$, with $0.0 \pm 0.0 \mathrm{mg} \mathrm{L}^{-1}$ total ammonia nitrogen, nitrites and nitrates. The fish 138 were hand-fed the prepared diets (CTRL, 1.1 DON or 2.7 DON) three times per day near 139 satiety for 50 days prior to performing the $Y$. ruckeri challenge.

\section{Long-term exposure to DON}

142 For the long-term exposure experiment, 120 fish weighing $89 \pm 8 \mathrm{~g}$ were randomly allocated 143 and distributed among eight tanks, each with a volume of $1 \mathrm{~m}^{3}$, supplied by a flow-through 144 system with a water temperature of $18.6 \pm 1.0 \mathrm{C}$, oxygen concentration of $8.56 \pm 0.26 \mathrm{mg} \mathrm{L}^{-1}$ 145 and $\mathrm{pH}$ of $7.35 \pm 0.35$. Each tank contained 15 fish that were fed restrictively $(2.5 \%$ of the 146 average body mass) with either control feed (CTRL, 4 tanks) or the control feed supplemented 147 with $367 \mu \mathrm{g} \mathrm{kg}^{-1} \mathrm{DON}$ (0.3 DON, 4 tanks) for 168 days. The same quantity of feed (2.5\% of 148 the average body mass) was distributed in each tank by hand feeding and was adjusted after 149 intermediate weighing periods (at 37, 62, 92 and 125 days). Five fish per replicate tank were 150 subjected to moderate anesthesia (tricaine methanesulfonate (MS222) (Sigma-Aldrich Co., 151 LLC, Bellfonte, USA) at a dose of $0.7 \mathrm{~g} \mathrm{~L}^{-1}$, and a blood sample was collected by puncture of 152 the caudal vein with a heparinized syringe at the beginning of the trial and at 62 and 125 days. 153 Part of the blood sample was used for the determination of hematocrit, which was determined 154 for five fish per treatment. Blood was transferred into hematocrit capillary tubes 
155 (Hirschmann), the tubes were then centrifuged at 13,000 RPM for 5 minutes (Hettich 156 Haematokrit 200), and the percentage of red blood cells to sera was measured. The remaining 157 part of the blood sample was centrifuged at 1,590 $\mathrm{x}$ g for ten minutes, after which the plasma 158 (i.e., the supernatant fraction) was transferred to Eppendorf tubes, snap-frozen in liquid 159 nitrogen and stored at $-80 \mathrm{C}$ until subsequent analysis of total protein. Total protein was 160 determined by the Bradford method (Bradford 1976) using bovine serum albumin as the 161 standard. All measurements were performed in a Synergy HT multi-mode microplate reader 162 (BIOTEK, Vermont, USA).

\section{Growth performance}

165 All fish, in both the short- and long-term exposure experiments, were weighed to determine 166 the initial individual body weight at the start of the experiments. In the short-term exposure 167 study, the fish were weighed individually at the end of the 50-day period, and their total 168 length was measured and recorded. Feed intake was recorded daily. In the long-term exposure 169 study, the fish were weighed individually after 37, 62, 92,125 and 168 days.

170 The following calculations were made in both experiments.

171 The thermal-unit growth coefficient (TGC) was expressed as the growth rate and was 172 calculated for each aquarium as $\left[100 \times(\mathrm{FBW} 1 / 3-\mathrm{IBW} 1 / 3) / \Sigma\left(\mathrm{Temp}\left({ }^{\circ} \mathrm{C}\right) \times\right.\right.$ number of 173 days)], where FBW $=$ final body weight $\left(\mathrm{g} \mathrm{fish}^{-1}\right)$ and IBW $=$ initial body weight $\left(\mathrm{g} \mathrm{fish}^{-1}\right)$.

174 The feed conversion ratio (FCR) was calculated as crude feed intake/weight gain, where FI = 175 total dry feed/number of fish.

176 The protein efficiency ratio (PER) was calculated as weight gain $(\mathrm{g}) /$ protein intake $(\mathrm{g})$.

177 The specific growth rate (SGR) was calculated as [(ln final weight $-\ln$ initial weight)/time in 178 days $] \times 100)$. 
179 Fulton's condition factor, $\mathrm{K}$, was also used to measure individual fish health: $\mathrm{K}=$

$180100\left(\mathrm{BW} / \mathrm{L}^{3}\right)$, where $\mathrm{BW}$ is the whole body wet weight $(\mathrm{g})$ and $\mathrm{L}$ is the length $(\mathrm{cm})$. A factor

181 of 100 was used to transform $\mathrm{K}$ to approximate a value of one.

182

183

184

185

186

187

188

189

190

191

192

193

194

195

196

197

\section{Liver enzymes}

In the short-term/high DON exposure experiment, five fish from each aquarium were sampled at the end of the experiment (50 days) for analysis of liver enzymes in blood. In the longterm/low DON exposure study, five fish from each aquarium were sampled on day 62 and on day 125. The fish were anesthetized by immersion in tricaine methanesulfonate (MS222) (Sigma-Aldrich Co., LLC, Bellfonte, USA) at a dose of $0.7 \mathrm{~g} \mathrm{~L}^{-1}$ prior to blood collection. Blood samples were analyzed to measure the activities of lactate dehydrogenase (LDH), alanine transaminase (ALT) and aspartate aminotransferase (AST) using a Spotchem EZ SP4430 reader and Spotchem II GPT/ALT, Spotchem II LDH and Spotchem II GOT/AST kits (all products from Arkay, Amstelveen, Netherlands).

\section{Histological examination}

For the short-term/high DON exposure study, organs were sampled from 10 fish prior to the Y. ruckeri challenge and at the time of termination. The intestine, spleen, liver and kidneys (head and trunk kidney) of the fish were removed and fixed in $10 \%$ buffered formalin for 48 to 72 hours. The samples were embedded overnight in paraffin using a HistoMaster (Formafix, Düsseldorf, Germany). Sections (3 - $4 \mu \mathrm{m}$ thick) were cut from each paraffin block and were left to dry overnight at $37 \mathrm{C}$ before being stained with hematoxylin and eosin. The slides were evaluated under a light microscope (Nikon Eclipse E400, Feasterville, Pennsylvania). The following were examined: intestine (number of mucous cells in mucosa), liver (hepatocyte vacuolation, hepatocyte hyalinization, single cell necrosis, number of pigmented macrophage centers, perivascular and peribiliary inflammation), and kidney 
205 (number of pigmented macrophage centers). To evaluate the number of cells, three high206 power fields (HPF) were counted per slide.

207

\section{Bacterial preparation}

As a pre-trial to the challenge test, five groups of ten fish each were challenged by immersion with $Y$. ruckeri isolate $7959 / 11$ to determine the appropriate infectious dose. $Y$. ruckeri isolate A7959/11 is a clinical isolate that originated from an outbreak at an Austrian trout farm in 2011. This isolate was kept at $-80 \mathrm{C}$ on beads until three days prior to the start of the experiment. It was then inoculated on a blood agar plate and incubated at $22 \mathrm{C}$. After 48 hours, a single colony was inoculated into $7.5 \mathrm{ml}$ of BHI broth and was incubated in a shaking incubator at $20 \mathrm{C}$ with rotation at $150 \mathrm{rpm}$. After 10 hours, the cultures were evaluated by eye, was then incubated for approximately 12 hours at $20 \mathrm{C}$ with shaking at $150 \mathrm{rpm}$.

\section{Infection trial in the short-term exposure study}

After 50 days, each feeding group of the short-term/high DON exposure study was further divided into two groups: two of the aquaria were infected with Y. ruckeri while fish in the two other aquaria were mock-infected with un-inoculated broth. In total, 90 fish were infected and 90 were mock-infected. The infection procedure was adapted from that described for Aeromonas salmonicida (Menanteau-Ledouble et al., 2017). Briefly, bacteria were grown overnight in $1.5 \mathrm{~L}$ of $\mathrm{BHI}$ broth and their concentration was determined by measuring the optical density at a wavelength of $600 \mathrm{~nm}(\mathrm{OD} 600)$ per ml. Water circulation in the aquarium was interrupted, and the water volume was lowered to $50 \mathrm{~L}$. The bacterial culture $(2 \mathrm{ml})$ was added to each of the aquaria, yielding a final concentration of $2 \times 10^{4} \mathrm{CFU} \mathrm{mL} \mathrm{m}^{-1}$. The fish remained in the solution for two hours, after which the water was progressively returned to its normal level and the circulation was reopened. The fish were monitored at least twice daily. 
231 Mortalities were recorded, and dead and moribund fish were immediately removed from the

232 tanks. Moribund fish were euthanatized by prolonged immersion in a solution of $1 \mathrm{~g} \mathrm{~L}^{-1}$ of

233 MS-222, and the kidney of the fish was sampled for microbial re-isolation of the pathogen on 234 an agar plate. The colonies growing on these plates were examined and confirmed to be $Y$. 235 ruckeri based on their morphologies. Furthermore, one in five isolates was selected; its 236 genomic DNA was isolated using a Qiagen DNeasy kit, and PCR was performed using $Y$. 237 ruckeri specific primers (del Cerro et al., 2002). The surviving fish overcame the infection 17 238 days post-infection, at which point the challenge was terminated. All remaining fish were 239 euthanatized by prolonged immersion in a solution of tricaine methanesulfonate (MS222; $1 \mathrm{~g}$ $240 \mathrm{~L}^{-1}$ of water), weighed, measured and examined for gross clinical signs of enteric red mouth 241 syndrome (oral congestion, hemorrhages or petechia, exophthalmia and ocular hemorrhages, 242 ascites in the abdominal cavity, enlarged spleens and hemorrhages or petechia in the internal 243 organs, bloody intestines or adipose tissues).

\section{Clinical signs}

246 During both experiments, gross clinical signs were assessed by visual examination of the fish 247 at the time of termination. Lesions (hemorrhages and ulcerations) on the skin were recorded, 248 as were any obvious abnormalities such as a protruding anal papilla. The state of the gills was 249 recorded as well as the presence of anemia, hemorrhages or necrosis.

250 The fish were examined internally for any abnormalities. In particular, record was made of 251 congestions, petechia or hemorrhages of the internal organs. The color of the liver and the size 252 of the spleen were assessed, as was the general health of the intestine (in particular, the 253 presence of congestion, hemorrhage or intussusception was determined). 
257 All parameters such as the final weight, SGR, PER, FI, FCR, condition factor (CF), TGC,

258 LDH, ALT and AST were subjected to analysis of variance in SPSS 21 for Windows (IBM

259 Corp., Armonk, NY, USA). One-way ANOVA was performed, and differences between the

260 means were tested by Tukey's multiple range test. The Shapiro-Wilk test was used to analyze

261 the normality, and homogeneity of variances was tested using Levene's test. Data analyzed

262 did not violate the assumption of equal variances and showed a normal distribution. All

263 parameters expressed as percentages were subjected to arcsin square root transformation.

264 Additionally, one-way ANOVA was performed to analyze the histological differences in the

265 intestine (number of mucous cells in mucosa) and liver (single cell necrosis, number of

266 pigmented macrophage centers, perivascular and peribiliary inflammation) between the DON

267 dietary treatments and controls.

268 Following the challenge, survival curves were constructed for each treatment, and Kaplan-

269 Meier and odds ratio analyses were performed using SPSS v.20 (IBM) and MedCalc 270 (Microsoft).

271 The level of significance was set at $\mathrm{p}<0.05$, and the results are presented as the mean \pm SD 272 (standard deviation of the mean).

273

274

275

276

\section{Results}

\section{Experimental diets}

The four experimental diets were formulated to be isoenergetic $\left(22.20 \mathrm{~kJ} \mathrm{~g}^{-1} \mathrm{DM}\right)$, isoproteic $(52.20 \% \mathrm{DM})$ and isolipidic $(17.90 \% \mathrm{DM})$ and to meet all the nutrient requirements for the species examined in the study. There was no significant difference $(p>0.05)$ between treatments regarding the nutritional composition of the experimental diets. Analysis of the feed to confirm mycotoxin levels showed DON contamination was successfully achieved, although observed levels were slightly lower than intended (Table 2). Other metabolites/toxins were found in the basal diet (common to all experimental groups) due to 
283 natural contamination of the plant raw materials used to formulate the diet (Table 2).

284 Generally, these metabolites/toxins, produced mainly by Fusarium and Aspergillus, were at 285 levels below $100 \mu \mathrm{g} \mathrm{kg}^{-1}$. Regarding the Penicillium toxins, brevianamide $\mathrm{F}$ and rugulusovin 286 were found at levels of 194 and $244 \mu \mathrm{g} \mathrm{kg}^{-1}$, respectively. Fungal and bacterial metabolites 287 were also detected in the experimental diets, namely, cyclo (L-Pro-L-Val) and cyclo (L-Pro288 L-Tyr) at relatively high concentrations (1,631 and 2,004 $\mu \mathrm{g} \mathrm{kg}^{-1}$, respectively).

\section{Growth performance}

\section{Short-term DON exposure}

292

The results showed that rainbow trout was sensitive to the DON levels tested (Table 3).

The presence of $2,700 \mu \mathrm{g} \mathrm{kg}^{-1} \mathrm{DON}$ in the diet led to a significant decrease $(\mathrm{p}<0.001)$ in FI.

The same treatment $(2.7 \mathrm{DON})$ also resulted in a significant decrease in the final weight

$(79.91 \pm 16.54 \mathrm{~g} ; \mathrm{p}<0.001)$, SGR $\left(2.20 \pm 0.09 \%\right.$ day $\left.^{-1} ; \mathrm{p}<0.001\right)$, TGC $(0.094 \pm 0.005 ; \mathrm{p}<$ $0.001)$ and $\mathrm{CF}(1.39 \pm 0.12 ; \mathrm{p}<0.033)$ compared to the controls (final weight $=101.36 \pm 19.8$ g; SGR $=2.52 \pm 0.07 \%$ day $^{-1} ;$ TGC $=0.113 \pm 0.005$ and $\left.\mathrm{CF}=1.42 \pm 0.12\right)$. Observations of the feeding behavior of the DON-fed groups confirmed that the fish initially accepted the feed, and a reduction in FI was progressively established. We therefore assumed that the lower FI in the DON-fed groups compared to the control group was probably not due to the unfavorable organoleptic properties of DON-contaminated feed.

\section{Long-term DON exposure}

304 In the long-term exposure study, the fish that received the contaminated diet also showed 305 lower farming performances (FBW, FCR and SGR) compared to the control. These 306 differences increased over time (Fig. 1, 2 and 3) and after 168 days of exposure to $367 \mu \mathrm{gg}^{-1}$ 307 DON, fish that ingested DON presented a final weight of $487.40 \mathrm{~g}$ compared to $593.63 \mathrm{~g}$ in 
308 the control group ( $\mathrm{p}=0.053$, Fig. 1). However, these differences were never statistically 309 significant.

310 A similar pattern of lower performance in the DON-fed animals was observed for FCR (Fig. 311 2) and SGR (Fig. 3): animals fed the control diet presented an FCR of 1.86 compared to 2.50 312 for DON-fed animals. PER was generally lower for animals that were fed DON and was 313 significantly lower on day $92(\mathrm{p}=0.044)$ and day $168(\mathrm{p}=0.050$; Table 4). Feed intake was 314 generally higher for animals that were fed DON and was significantly higher on day 62 ( $\mathrm{p}=$ 315 0.041; Table 5).

\section{Histology}

In the short-term exposure study, among the 2.7 DON groups, two out of ten animals showed mild to moderately hyalinized hepatocytes. In one trout, multiple areas of necrosis with scattered hemorrhages were present (Fig. 4). Vacuolation of hepatocytes was also more pronounced in 2.7 DON animals (5 out of 10 fish) compared to the control animals (no registered cases of vacuolation of hepatocytes). In the 1.1 DON groups, hyalinized hepatocytes were visible (6 out of 10 fish), but to a lesser extent compared with the 2.7 DON groups ( 8 out of 10 fish). No significant differences were obvious between any of the experimental groups based on counts of the mucous cell numbers in the intestinal mucosa, pigmented macrophage centers in the liver and kidney, and number of necrotic single cells in 327 the liver. No histological alterations were found in the intestine or kidneys (head and trunk 328 kidney).

331 Cumulative mortality after inoculation with Y. ruckeri is shown in Figure 5. The challenge 332 trial lasted 17 days, and the 2.7 DON treatment showed a significantly higher survival rate (p $333<0.020)$ compared to the control treatment. Controls exhibited $73.3 \%$ survival while the 1.1 
334 DON and 2.7 DON treatments had a survival rate of $86.7 \%$ and $93.3 \%$, respectively. No 335 statistically significant differences were found between the 1.1 DON and 2.7 DON treatments 336 or between the $1.1 \mathrm{DON}$ treatment and the controls. The cause of death was confirmed as $Y$. 337 ruckeri on the basis of the clinical signs. Furthermore, bacteria were re-isolated from the 338 kidneys of infected fish. In each case, pure cultures were obtained, and the colonies displayed 339 morphology consistent with Y. ruckeri. This was further confirmed by isolating the genomic 340 DNA from selected colonies and performing PCR using the primers described by del Cerro et 341 al. (2002). Fish that had recovered from the infection at the time of the challenge termination 342 did not display any gross clinical signs. Similarly, non-infected fish did not display any signs 343 of infection.

344

345

346

347

348

349

350

351

352

353

354

355

356

357

358

\section{Liver Enzymes}

Short-term DON exposure

The effects of the dietary treatments on LDH, ALT and AST activities in the serum are summarized in Table 6. Samples from the fish that received the dietary DON appeared to have a higher LDH activity, although these results were not statistically significant $(\mathrm{p}=$ 0.078). The 2.7 DON treatment showed a significant increase in ALT and AST activities $\left(76.10 \pm 9.88 \mathrm{IU} \mathrm{L}^{-1} ; \mathrm{p}<0.001\right.$ and $876.50 \pm 87.60 \mathrm{IU} \mathrm{L}^{-1} ; \mathrm{p}<0.001$, respectively) compared with the control $\left(\mathrm{ALT}=14.20 \pm 7.66 \mathrm{IU} \mathrm{L}^{-1}\right.$ and AST $=389.70 \pm 2.36 \mathrm{IU} \mathrm{L}^{-1}$; Table 6).

\section{Long-term DON exposure}

Blood enzyme parameters measured at different sampling points are shown in Table 7. No significant differences were found during the experimental period for the different enzymes sampled. 


\section{Clinical signs}

360 Few clinical signs were observed in the fish exposed to the mycotoxin, and when 361 abnormalities were observed, only a small number of fish were affected. Among the 362 abnormalities were abnormal body conformations, observed in 15 out of 60 fish that were fed $3632,745 \pm 330 \mu \mathrm{g} \mathrm{kg}^{-1} \mathrm{DON}$, characterized by a reduction in fish length in relation to width 364 (Figure 6). In addition, in five out of 60 fish that were fed $2,745 \pm 330 \mu \mathrm{g} \mathrm{kg}^{-1} \mathrm{DON}$, a 365 protruding anal papilla was observed (Figure 7). Intussusceptions were observed internally in 366 two fish.

\section{Discussion}

The decreasing supply and rising cost of fishmeal have led the aquaculture industry to investigate alternative sources of protein to substitute fishmeal in aquafeeds. Plant-based

371 meals seem to be one of the most promising solutions for replacing fishmeal, and numerous 372 plant raw materials have been successfully tested (Gatlin et al., 2007). However, recent 373 studies have noted the occurrence of mycotoxins in plant-based aquafeeds (Barbosa et al., 374 2013, Pietsch et al., 2013; Nácher-Mestre et al., 2015; Gonçalves et al., 2016; Gonçalves et 375 al., 2017, Greco et al., 2015). In the present study, the experimental diets were contaminated 376 with several mycotoxins and fungal metabolites in addition to the added DON. The presence 377 of other mycotoxins and fungal metabolites highlights the risk of mycotoxin contamination in 378 aquaculture finished feeds. The present experimental diet represents a typical commercial 379 trout diet that contains plant-based compounds $(59.70 \% \mathrm{DM})$. The co-occurrence of 380 mycotoxins and fungal metabolites in this diet, even at low concentrations, may lead to 381 synergistic/additive/antagonistic effects between these compounds, which cannot be ruled out 382 as a contributing factor for the obtained results. However, further studies are needed to 383 address possible interactions between mycotoxins, especially at low contamination levels. 
384 The objective of the present trial was to evaluate the possible effects of DON contamination 385 in aquaculture feeds under two different scenarios. In the first scenario, the effect of short386 term feeding of high levels of DON (50 days; $1,166 \mu \mathrm{g} \mathrm{kg}^{-1} \mathrm{DON}$ and 2,745 $\mu \mathrm{g} \mathrm{kg}^{-1} \mathrm{DON}$ ) 387 was examined in an attempt to mimic the potential inclusion of highly contaminated raw 388 material(s) in the finished feed. This situation would normally only affect a few batches of 389 feed; therefore, the exposure would occur over a short period. In this scenario, the potential 390 influence of mycotoxins on Y. ruckeri susceptibility was also evaluated. The second 391 experiment studied the effects of long-term exposure to low levels of DON (168 days; $367 \mu \mathrm{g}$ $\left.392 \mathrm{~kg}^{-1} \mathrm{DON}\right)$. This experiment was designed to replicate a situation that is more commonly 393 found because $367 \mu \mathrm{g} \mathrm{kg}^{-1}$ DON is comparable to the average DON contamination level 394 previously found in aquafeeds during recent years (Gonçalves et al., 2016, 2017, and 2018).

395 One of the main constraints when researching mycotoxins in aquaculture species is the lack of 396 mycotoxin-induced clinical symptoms. While it is true that several published reports describe 397 some clinical signs for the most common mycotoxins (see the review conducted by Anater $e t$ $398 a l ., 2016)$, most of these clinical signs are very general and can be attributed to any other 399 pathology or challenge faced by the animals, e.g., anti-nutrition factors or lectins in the diet 400 (Hart et al., 2010). Furthermore, the clinical signs typically present high variability.

401 In the present manuscript, the occurrence of clinical signs was evaluated in both the short- and 402 long-term exposure experiments, and special attention was paid to visual clinical signs. In the 403 short-term/high DON exposure experiment, 15 out of 60 fish that were fed $2,745 \pm 330 \mu \mathrm{g} \mathrm{kg}^{-}$ $404{ }^{1}$ DON showed an abnormal body conformation, characterized by a fish length reduced in 405 relation to its width, and five out of 60 fish from same treatment presented a protruding anal 406 papilla. No clinical signs were observed after long-term exposure/low DON exposure. 407 Although clinical manifestation was observed in a small number of individuals (only at the 408 higher dosage of the short-term/high DON exposure experiment), it cannot be concluded that 409 the signs observed are directly attributed to DON. The rectal prolapse observed in some fish is 
410 also described as a DON clinical manifestation in swine when fed $3,000 \mu \mathrm{g} \mathrm{kg}^{-1} \mathrm{DON}$

411 (Madson et al. 2014). However, a recent study (Gonçalves et al. 2018) stated that no

412 macroscopic lesions were found (i.e., internal or external hemorrhages, dermal and oral

413 lesions, abnormal pigmentation or damage to fins) on rainbow trout that were fed high levels

414 of DON $\left(11,412 \pm 1141 \mu \mathrm{g} \mathrm{kg}^{-1}\right)$. Taking into account the previous study (Gonçalves et al.

415 2018) and three other studies with the same range of DON contamination (0.3 to $5.9 \mathrm{ppm}$ ),

416 Hooft et al. (2011) and Ryerse et al. (2015) also reported no major pathological changes in

417 the distal intestine of trout, while Matejova et al. (2014) found gastrointestinal hemorrhages.

418 It is possible that the impact of DON might vary greatly depending on unknown factors, even

419 for the same species.

420 Recently, Gonçalves et al. (2018) reported a novel DON metabolite (DON-3-sulfate) found in

421 rainbow trout feces. The authors suggested that this biotransformation achieved by sulfation is

422 probably realized by the trout gut microbiota as was previously described for other fish

423 species (Ameiurus nebulosus; Guan et al., 2009). This biotransformation, if achieved by the 424 gut microbiota, can also help to explain the high individual variability obtained, as the 425 capacity to metabolize DON will be directly influenced by the individual fish microbiome. 426 This explains the absence of clinical signs in some of the fish that were fed DON because 427 DON-3-sulfate is less toxic than DON. The high inter-individual variation within the groups 428 that were fed mycotoxins highlights the importance of the individual health and nutritional 429 status prior to DON ingestion, as supported by other authors (Hendricks, 1994). Due to the 430 reasons previous stated, the clinical manifestation found in the present study, even if only 431 present in a small number of individuals, should be further confirmed as a DON exclusive 432 clinical sign, associating it with an individual fish microbiome.

433 Reduction in feed intake is a well-documented response of rainbow trout to diets 434 contaminated with naturally occurring or artificially added DON (Hooft et al., 2011; 435 Gonçalves et al. 2018; Ryerse et al., 2015). In the present short-term study, fish that were fed 
$4362,745 \mu \mathrm{g} \mathrm{kg}^{-1}$ of DON showed a significant reduction $(\mathrm{p}<0.001)$ in feed intake. However, no

437 effect was observed in fish that were fed $1,166 \mu \mathrm{g} \mathrm{kg}^{-1}$ of DON. A significant decrease in 438 growth was also detected in the 2.7 DON treatment; TGC decreased by $17 \%(\mathrm{p}=0.001)$, and 439 SGR decreased by $13 \%(p<0.001)$. However, no significant differences $(p>0.05)$ were 440 found for PER or FCR. In the long-term study, ingestion of DON was asymptomatic, as the 441 animals presented no clinical signs, and growth rate was slightly affected only after 92 days of 442 ingesting DON. At the end of the trial (168 days), the animals that were fed DON weighed 443 less than the control animals. While not significantly different, the tendency for reduced 444 weight gain in animals that were fed DON is consistent with the short-term experiment. 445 Recently, Gonçalves et al. (2018) suggested that suppression of appetite due to DON 446 contamination in feeds might be a defense mechanism to decrease the exposure of the animal 447 to DON, therefore reducing the potential negative impacts of DON. The authors showed that 448 PACAP (pituitary adenylate cyclase-activating polypeptide) seems to be fundamental for 449 explaining the reduction of feed intake in DON-fed treatments, inducing anorexia, reinforcing 450 the influence of DON on the hypothalamic melanocortin system. It is also important to 451 mention that a contamination dose of $367 \mu \mathrm{g} \mathrm{kg}^{-1}$ of DON is a frequent and plausible level of 452 contamination that is often found in aquafeeds incorporating plant meals (Gonçalves et al., 453 2016; Gonçalves et al., 2017). Moreover, this value is close to the limit of detection of most 454 commercial ELISA (enzyme-linked immunosorbent assay) strip tests for DON, which means 455 that samples need to be analyzed by more robust methods (e.g., HPLC), which increases costs 456 and the time to receive sample results. The observed asymptomatic decrease in growth 457 performance may lead to important economic consequences for the aquaculture industry.

458 In both experiments, it was difficult to correctly diagnose DON intake using the other 459 parameters evaluated (liver enzymes and histology). In the short-term/high DON exposure 460 study, histological and enzymatic changes showed different results, and individual variability 461 was very high. Enzymatic activity was used to evaluate the possibility of tissue destruction. 
462 ALT and AST have previously been used as markers of liver dysfunction (Gül et al., 2004;

463 Saravanan et al., 2012), and ALT is an intracellular enzyme that has been used as a marker of 464 tissue destruction in the liver. However, no clear pattern could be observed in the studies. 465 Only in the short-term/high-level DON exposure study were elevated ALT serum levels found 466 in the 2.7 DON treatment compared with the control group. In addition, AST values were 467 significantly higher in the $2.7 \mathrm{DON}$ treatment compared with the control. Elevated ALT and 468 AST serum levels might be an indication of liver or other parenchymal organ damage. Liver 469 histopathology revealed mild to moderate damage in a limited number of DON-exposed fish. 470 However, no histological alterations were detected in the intestine or kidneys (head and trunk 471 kidney). DON is known to cause impairment of barrier integrity, affecting the lamina propria 472 and tight junctions, which may increase GIT permeability and consequently allow the entry of 473 luminal antigens and bacteria normally restricted to the GIT lumen (Grenier et al., 2013, 474 Dänicke et al., 2010). The fact that histological alterations were not found in the intestines, 475 despite the altered values of ALT and AST, might lead us to hypothesize that short exposure 476 periods might not be sufficient to lead to histological alterations and/or that histology might 477 not be a good method to evaluate negative DON effects in the intestines. Moreover, as 478 mentioned by Gonçalves et al. (2018), the individual microbiome seems to play an important 479 role in DON biotransformation, which may also influence the obtained histological results. It 480 would also be interesting to more closely examine the tight junction proteins as a more 481 sensitive indicator for possible DON impact at the intestinal barrier, specifically at the tight 482 junction level.

483 The results obtained for the $Y$. ruckeri challenge are consistent with the results from previous 484 studies that investigated the effect of dietary DON on the mortality of rainbow trout 485 challenged with other bacterial pathogens (Hooft et al. (2011) and Ryerse et al. (2015)). The 486 apparent absence of an immunosuppressive effects on trout challenged with DON contrasts 487 with published data for livestock species such as swine (Lessard et al., 2015; Pierron et al., 
488 2016). An eventual direct suppression of $Y$. ruckeri by DON seems unlikely as it is very well

489 described that trichothecenes interact with the eukaryotic $60 \mathrm{~S}$ ribosomal subunit and prevent 490 polypeptide chain initiation or elongation (Carter and Cannon, 1977; Ueno, 1984; Pestka, 491 2007). The present study did not include a pair-fed group (i.e., a group consuming the same 492 amount of feed as that consumed by the DON groups), and thus it was not possible to 493 distinguish the effects of feed restriction (caused by DON) from other effects of DON that 494 might have decreased susceptibility to Y. ruckeri.

495 The intake of DON has been reported to lead to the upregulation of cytokine levels, especially 496 pro-inflammatory cytokines (IL-6, IL-8 and IL-1 $\beta$ ), in several studies (piglets, Bracarense et 497 al. 2012); human intestinal Caco-2 cells (Maresca et al. 2008, Van De Walle et al. 2008); and 498 mice (Azcona-Olivera et al. 1995)). Intestinal upregulation of pro-inflammatory cytokines 499 may explain the higher resistance of DON-treated fish to infection with Y. ruckeri. However, 500 as explained by Grenier and Applegate (2013), DON, as a protein synthesis inhibitor, might 501 naturally originate superinduction phenomena, consequently increasing cytokine synthesis 502 and secretion. Nonetheless, the possible role of DON in the upregulation of pro-inflammatory 503 cytokines and the consequent effect on immune stimulation should be further investigated.

504

505

506

507

508

509

510

511

512

513

\section{Conclusions}

The present findings reinforce those from previous studies, concluding that the ingestion of DON by trout over short-term periods at high dosages (50 days; $1,166 \mu \mathrm{g} \mathrm{kg}^{-1}$ and 2,745 $\mu \mathrm{g}$ $\mathrm{kg}^{-1}$ ) impacts growth performance, especially feed intake, with minor or variable biochemical changes in trout blood and histopathological changes. In this case, some fish did exhibit clinical symptoms (i.e., anal papilla), which could be attributed to the DON treatment; however, further confirmation is needed. This is the first report of the effects of the long-term exposure of rainbow trout to low concentrations of DON (168 days; $367 \mu \mathrm{g} \mathrm{kg}^{-1} \mathrm{DON}$ ). Ingestion of DON in the long-term study was asymptomatic; however, the fish started to 
514 reduce their growth performance 92 days after ingesting DON. Such low contamination

515 levels, which might be unnoticed by farmers, may have economic consequences for 516 aquaculture.

517 DON-treated fish showed higher resistance to infection with $Y$. ruckeri, which may be related 518 to stimulation of the pro-inflammatory response. While higher resistance to pathogen 519 infection may be considered as a positive effect, the reduced feed intake and lower growth 520 performance may have economic consequences for aquaculture. Moreover, further 521 investigation is needed to understand the influence of DON on pro-inflammatory responses.

522 The high levels of individual variability observed in the blood biochemical parameters, 523 histological changes and clinical signs in the fish that were fed DON might be explained by 524 individual intestinal microbiota composition. The individual gut microbiome and its apparent 525 capacity to metabolize DON should be further explored.

\section{Acknowledgments}

We thank many of our colleagues at BIOMIN, especially Dr. Dian Schatzmayr, Dr. Christiane Gruber-Dorninger and Caroline Noonan, and our colleagues at the University of Veterinary Medicine for helpful discussions and critical review of the manuscript.

\section{Literature cited}

Anater, A., L. Manyes, G. Meca, E. Ferrer, F. Bittencourt Luciano, C. Turra Pimpão and G. Font (2016). "Mycotoxins and their consequences in aquaculture: A review." Aquaculture 451: $1-10$.

Azcona-Olivera, J. I., Ouyang, Y., Murtha, J., Chu, F. S. \& Pestka, J. J. 1995. Induction of cytokine mRNAs in mice after oral exposure to the trichothecene vomitoxin (deoxynivalenol): relationship to toxin distribution and protein synthesis inhibition. Toxicology Applied Pharmacology, 133, 109-120.

Barbosa, T., Pereyra, C., Soleiro, C., Dias, E., Oliveira, A., Keller, K., Silva, P.P., Cavaglieri, L. and Rosa, C.A., (2013). "Mycobiota and mycotoxins present in finished fish feeds from farms in the Rio de Janeiro State, Brazil." International Aquatic Research 5: 3.

Bracarense, A. P., Lucioli, J., Grenier, B., Drociunas Pacheco, G., Moll, W. D., Schatzmayr, G. \& Oswald, I. P. 2012. Chronic ingestion of deoxynivalenol and fumonisin, alone or in 
interaction, induces morphological and immunological changes in the intestine of piglets. Brasilian Journal Nutrition, 107, 1776-1786.

Bradford, M.M., 1976. A rapid and sensitive method for the quantitation of microgram quantities of protein utilizing the principle of protein-dye binding. Analytical Biochemistry 72: 248-254.

Carter, C.J. and M. Cannon (1977). "Structural requirements for the inhibitory action of 12,13epoxytrichothecenes on protein synthesis in eukaryotes." Biochemical Journal 166(3): 399409.

Dänicke, S., Valenta, H. and Döll, S., (2004). "On the toxicokinetics and the metabolism of deoxynivalenol (don) in the pig." Archives of Animal Nutrition 58: 169-180.

Davis, D.A. and D. Sookying (2009). Strategies for reducing and/or replacing fishmeal in production diets for the Pacific white shrimp, Litopenaeus vannamei. The Rising Tide, Proceedings of the Special Session on Sustainable Shrimp Farming., Baton Rouge, USA, World Aquaculture Society., World Aquaculture 2009.

del Cerro, A., I. Marquez and J.A. Guijarro (2002). "Simultaneous Detection of Aeromonas salmonicida, Flavobacterium psychrophilum, and Yersinia ruckeri, Three Major Fish Pathogens, by Multiplex PCR." Applied Environmental Microbiology 68(10) p.5177-5180.

Devreese, M., G. Antonissen, N. Broekaert, T. De Mil, S. De Baere, L. Vanhaecke, P. De Backer and S. Croubels (2015). "Toxicokinetic study and oral bioavailability of deoxynivalenol in turkey poults, and comparative biotransformation between broilers and turkeys." World Mycotoxin Journal 8(4): 533-539.

Gatlin, D.M., F.T. Barrows, P. Brown, K. Dabrowski, T.G. Gaylord, R.W. Hardy, E. Herman, G. Hu, Å. Krogdahl, R. Nelson, K. Overturf, M. Rust, W. Sealey, D. Skonberg, E.J. Souza, D. Stone, R. Wilson and E. Wurtele (2007). "Expanding the utilization of sustainable plant products in aquafeeds: a review." Aquaculture Research 38: 551-579.

Gonçalves, R.A., K. Naehrer and G.A. Santos (2016). "Occurrence of mycotoxins in commercial aquafeeds in Asia and Europe: a real risk to aquaculture?" Reviews in Aquaculture: n/a-n/a.

Gonçalves, R.A., D. Schatzmayr, U. Hoffstetter and G.A. Santos (2017). "Occurrence of mycotoxins in aquaculture: preliminary overview of Asian and European plant ingredients and finished feeds." World Mycotoxin Journal 10(2): 183-194.

Gonçalves, R.A., Hofstetter, U., Schatzmayr, D. and Jenkins, T., (2018). "Mycotoxins in Southeast Asian aquaculture: plant-based meals and finished feeds". World Mycotoxin Journal. In Press

Gonçalves, R. A., Navarro-Guillén, C., Gilannejad, N., Dias, J., Schatzmayr, D., Bichl, G., Czabany, T., Moyano, F. J., Rema, P., Yúfera, M., Mackenzie, S. \& Martínez-Rodríguez, G. (2018). "Impact of deoxynivalenol on rainbow trout: Growth performance, digestibility, key gene expression regulation and metabolism." Aquaculture. In Press

Greco, M., Pardo, A. and Pose, G., (2015). "Mycotoxigenic Fungi and Natural Co-Occurrence of Mycotoxins in Rainbow Trout (Oncorhynchus mykiss) Feeds." Toxins 7: 4595.

Grenier, B. \& Applegate, T. 2013. "Modulation of Intestinal Functions Following Mycotoxin Ingestion: Meta-Analysis of Published Experiments in Animals." Toxins, 5, 396.

Guan, S., J. He, J.C. Young, H. Zhu, X.-Z. Li, C. Ji and T. Zhou (2009). "Transformation of trichothecene mycotoxins by microorganisms from fish digesta." Aquaculture 290(3-4): 290295.

Gül, Ş., E. Belge-Kurutaş, E. Yildiz, A. Sahan and F. Doran (2004). "Pollution correlated modifications of liver antioxidant systems and histopathology of fish (Cyprinidae) living in Seyhan Dam Lake, Turkey." Environment International 30(5): 605-609.

Hart, S.D., A.S. Bharadwaj and P.B. Brown (2010). "Soybean lectins and trypsin inhibitors, but not oligosaccharides or the interactions of factors, impact weight gain of rainbow trout (Oncorhynchus mykiss)." Aquaculture 306(1): 310-314.

Hendricks, J.D. (1994). Carcinogenicity of aflatoxins in nonmammalian organisms. Toxicology of Aflatoxins: Human Health, Veterinary, and Agricultural Significance. D.L. Eaton and J.D. Groopman, (Eds.). San Diego, Academic Press. 103-136.

Hooft, J.M. and D.P. Bureau (2017). "Evaluation of the efficacy of a commercial feed additive against the adverse effects of feed-borne deoxynivalenol (DON) on the performance of rainbow trout (Oncorhynchus mykiss)." Aquaculture 473: 237-245. 
Hooft, J.M., A.E.H.I. Elmor, P. Encarnação, and D.P. Bureau (2011). "Rainbow trout (Oncorhynchus mykiss) is extremely sensitive to the feed-borne Fusarium mycotoxin deoxynivalenol (DON)." Aquaculture 311(1-4): 224-232.

Krogdahl, Å., M. Penn, J. Thorsen, S. Refstie and A-M Bakke (2010). "Important antinutrients in plant feedstuffs for aquaculture: an update on recent findings regarding responses in salmonids." Aquaculture Research 41: 333-344.

Kumar, V., S. Roy, D. Barman and W. Anand (2013). "Importance of mycotoxins in aquaculture feeds." Aquatic Aminal Health XVIII(1).

Lessard, M., C. Savard, K. Deschene, K. Lauzon, V.A. Pinilla, C.A. Gagnon, J. Lapointe, F. Guay and Y. Chorfi (2015). "Impact of deoxynivalenol (DON) contaminated feed on intestinal integrity and immune response in swine." Food and Chemical Toxicology 80: 7-16.

Matejova, I., Modra, H., Blahova, J., Franc, A., Fictum, P., Sevcikova, M. and Svobodova, Z., (2014). "The effect of mycotoxin deoxynivalenol on haematological and biochemical indicators and histopathological changes in rainbow trout (Oncorhynchus mykiss)." Biomedical Research International 2014: 310680.

Matejova, I., M. Vicenova, L. Vojtek, H. Kudlackova, K. Nedbalcova, M. Faldyna, E. Sisperova, H. Modra and Z. Svobodova (2015). "Effect of the mycotoxin deoxynivalenol on the immune responses of rainbow trout (Oncorhynchus mykiss)." Veterinarni Medicina 60: 515521.

Matejova, I. , Svobodova, Z. , Vakula, J. , Mares, J. and Modra, H. (2017), Impact of Mycotoxins on Aquaculture Fish Species: A Review. J World Aquacult Soc, 48: 186-200. doi:10.1111/jwas.12371.

M. Madson, D., Ensley, S., Patience, J., Gauger, P. \& G. Main, R. (2014). "Diagnostic assessment and lesion evaluation of chronic deoxynivalenol ingestion in growing swine."

Maresca, M., Yahi, N., Younes-Sakr, L., Boyron, M., Caporiccio, B. \& Fantini, J. (2008). "Both direct and indirect effects account for the pro-inflammatory activity of enteropathogenic mycotoxins on the human intestinal epithelium: stimulation of interleukin-8 secretion, potentiation of interleukin-1beta effect and increase in the transepithelial passage of commensal bacteria." Toxicological Applied Pharmacology, 228, 84-92.

Menanteau-Ledouble, S., Krauss, I., Goncalves, R.A., Weber, B., Santos, G.A. and El-Matbouli, M., (2017). "Antimicrobial effect of the Biotronic ${ }^{\circledR}$ Top3 supplement and efficacy in protecting rainbow trout (Oncorhynchus mykiss) from infection by Aeromonas salmonicida subsp. salmonicida." Research in Veterinary Science 114: 95-100.

Nácher-Mestre, J., R. Serrano, E. Beltrán, J. Pérez-Sánchez, J. Silva, V. Karalazos, F. Hernández and M.H.G. Berntssen (2015). "Occurrence and potential transfer of mycotoxins in gilthead sea bream and Atlantic salmon by use of novel alternative feed ingredients." Chemosphere 128: 314-320.

Pestka, J.J. (2007). "Deoxynivalenol: Toxicity, mechanisms and animal health risks." Animal Feed Science and Technology 137(3-4): 283-298.

Pierron, A., I. Alassane-Kpembi and I.P. Oswald (2016). "Impact of mycotoxin on immune response and consequences for pig health." Animal Nutrition 2(2): 63-68.

Pietsch, C., S. Kersten, P. Burkhardt-Holm, H. Valenta and S. Dänicke (2013). "Occurrence of Deoxynivalenol and Zearalenone in Commercial Fish Feed: An Initial Study." Toxins 5(1): 184.

Ryerse, I.A., J.M. Hooft, D.P. Bureau, M.A. Hayes and J.S. Lumsden (2015). "Purified deoxynivalenol or feed restriction reduces mortality in rainbow trout, Oncorhynchus mykiss (Walbaum), with experimental bacterial coldwater disease but biologically relevant concentrations of deoxynivalenol do not impair the growth of Flavobacterium psychrophilum." Journal of Fish Diseases 38(9): 809-819.

Saravanan, M., K. Usha Devi, A. Malarvizhi and M. Ramesh (2012). "Effects of Ibuprofen on hematological, biochemical and enzymological parameters of blood in an Indian major carp, Cirrhinus mrigala." Environmental Toxicology and Pharmacology 34(1): 14-22.

Schwartz-Zimmermann, H.E., P. Fruhmann, S, Dänicke, G. Wiesenberger, S. Caha, J. Weber and F. Berthiller (2015). "Metabolism of deoxynivalenol and deepoxy-deoxynivalenol in broiler chickens, pullets, roosters and turkeys." Toxins (Basel) 7(11): 4706-4729. 
Streit, E., C. Schwab, M. Sulyok, K. Naehrer, R. Krska and G. Schatzmayr (2013). "Multimycotoxin screening reveals the occurrence of 139 different secondary metabolites in feed and feed ingredients." Toxins (Basel) 5(3): 504-523.

Tacon, A.G.J., M.R. Hasan and M. Metian (2011). "Demand and supply of feed ingredients for farmed fish and crustaceans: trends and prospects." FAO Fisheries and Aquaculture Technical Paper No. 564: 87.

Tola, S., D.P. Bureau, J.M. Hooft, F.W.H. Beamish, M. Sulyok, R. Krska, P. Encarnação and R. Petkam (2015). "Effects of Wheat Naturally Contaminated with Fusarium Mycotoxins on Growth Performance and Selected Health Indices of Red Tilapia (Oreochromis niloticus $\times O$. mossambicus)." Toxins 7(6): 1929.

Ueno, Y. (1984). "Toxicological features of T-2 toxin and related trichothecenes." Fundamental and Applied Toxicology 4(2): S124-S132.

Van De Walle, J., Romier, B., Larondelle, Y. \& Schneider, Y. J. (2008). "Influence of deoxynivalenol on NF-kappaB activation and IL-8 secretion in human intestinal Caco-2 cells." Toxicol Lett, 177, 205-214.

Wan, D., L. Huang, Y. Pan, Q. Wu, D. Chen, Y. Tao, X. Wang, Z. Liu, J. Li, L. Wang and Z. Yuan (2014). "Metabolism, Distribution, and Excretion of Deoxynivalenol with Combined Techniques of Radiotracing, High-Performance Liquid Chromatography Ion Trap Time-ofFlight Mass Spectrometry, and Online Radiometric Detection." Journal of Agricultural and Food Chemistry 62(1): 288-296. 


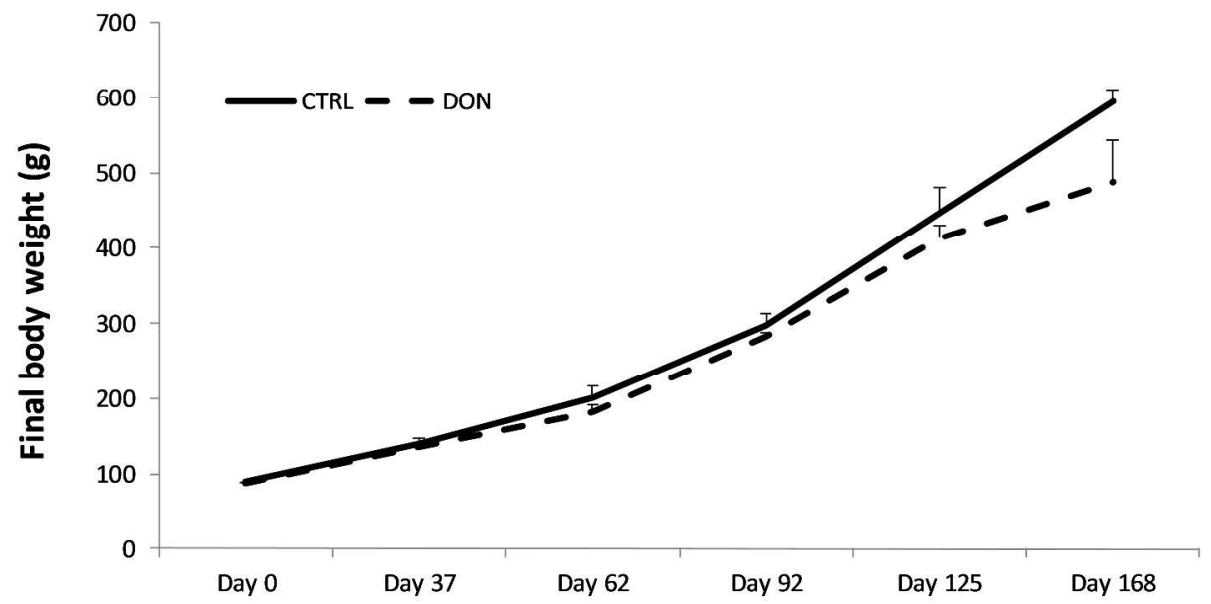

FIGURE 1: Growth curve representing the average weight of the fish during the long term experiment. 


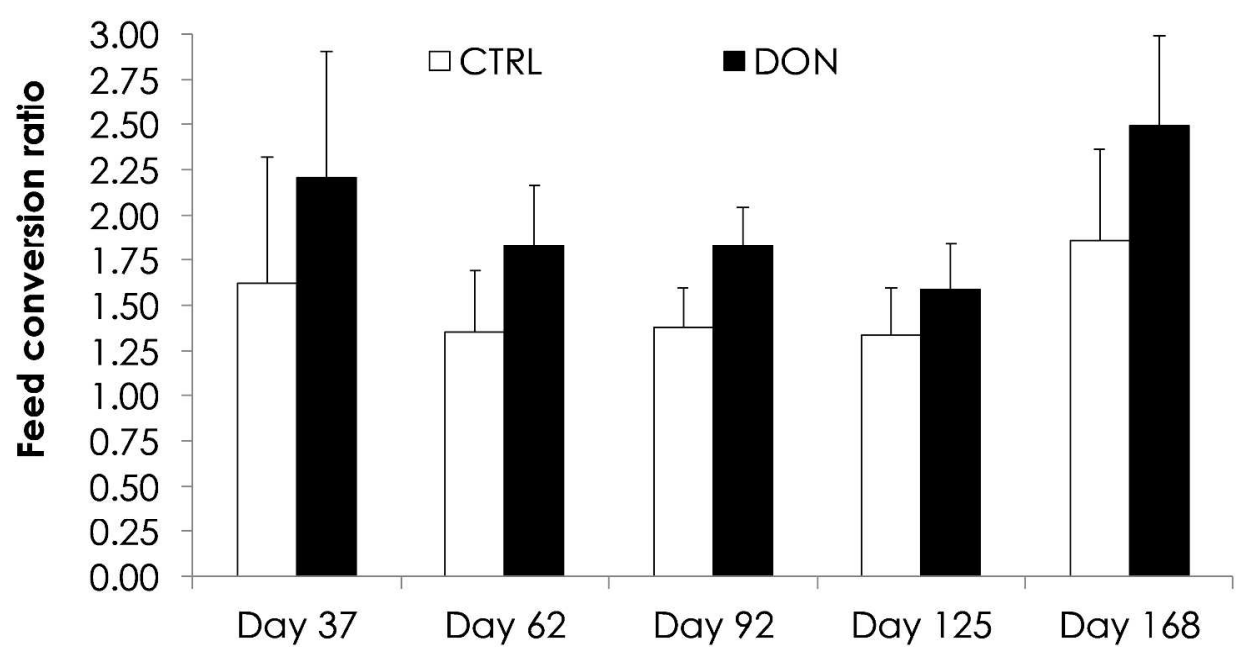

FIGURE 2: Feed conversion ratio at different sampling time points. Values are displayed as average \pm standard deviation. 


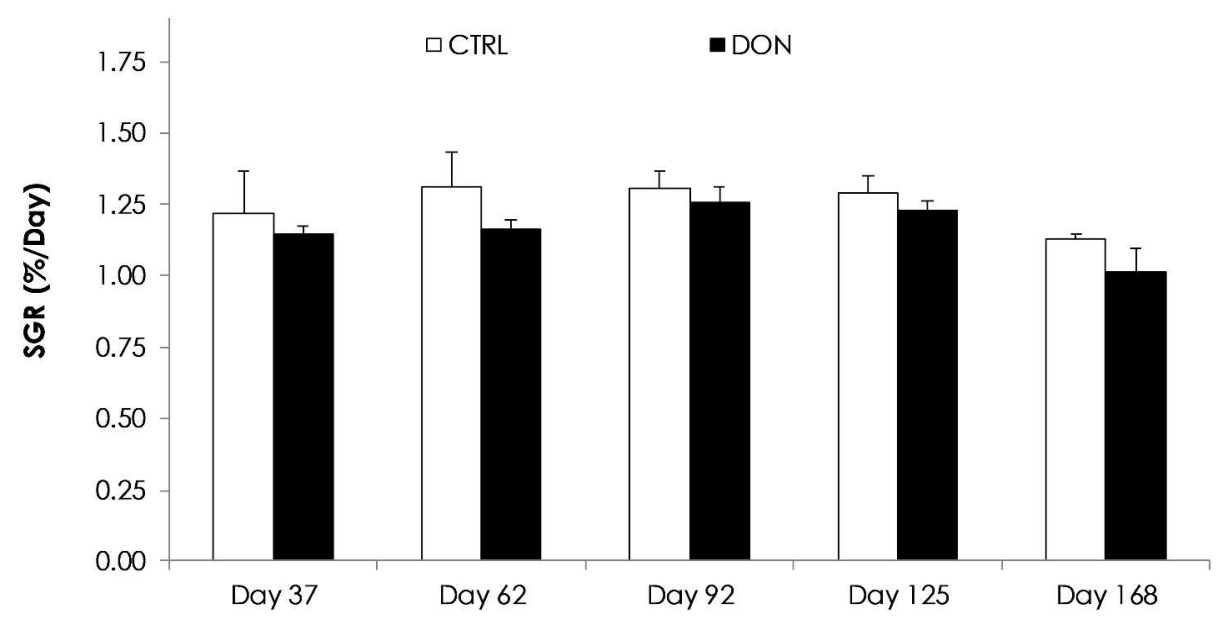

FIGURE 3: Specific growth rate at different sampling time points. Values are displayed as average \pm standard deviation. 


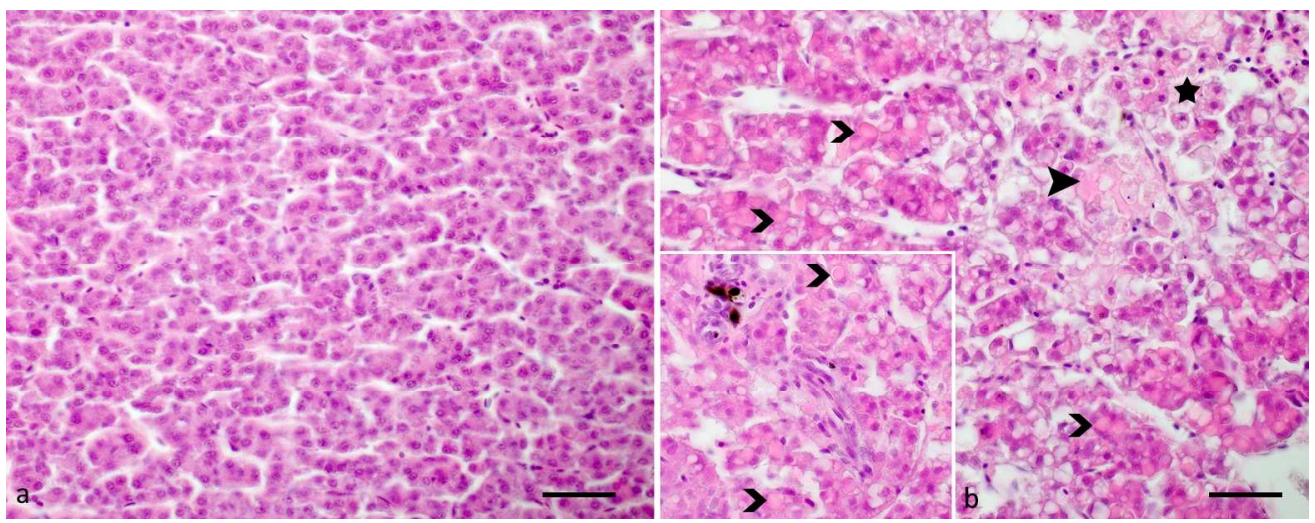

FIGURE 4. Onchorhynchus mykiss, histologic appearance of control (a) and 2.7 DON exposed fish (b); a. normal structure of hepatocytes; b. normal structure is disrupted, multiple hepatocytes are necrotic (star; observed in 1 out of 10 fishes sampled), scattered fibrin exudation (closed arrowhead; observed in 6 out of 10 fishes sampled), multiple hepatocytes show intracytoplasmatic eosinophilic, amorphous material (hyalinised hepatocytes) (open arrowheads; observed in 8 out of 10 fishes sampled), HE stain, bars $=50$ $\mu \mathrm{m}$; inlet: higher magnification showing hyalinised hepatocytes (open arrowheads).

$180 \times 70 \mathrm{~mm}(300 \times 300 \mathrm{DPI})$ 


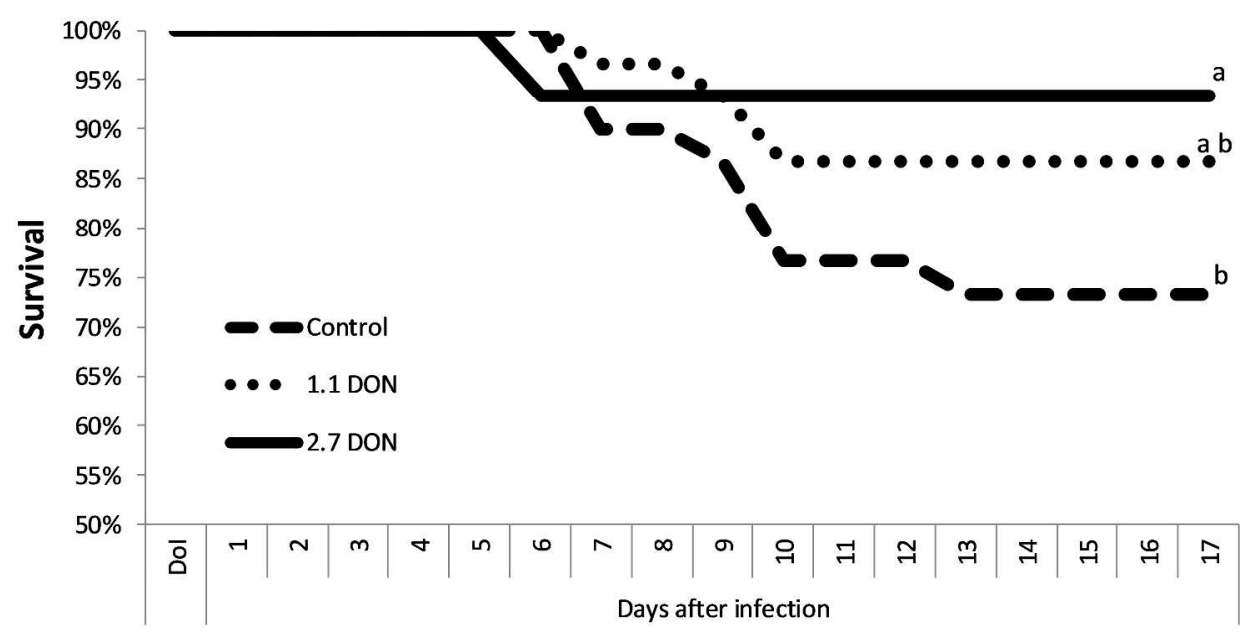

FIGURE 5. Survival curve following infection with Yersinia ruckeri during the high dose experiment. 


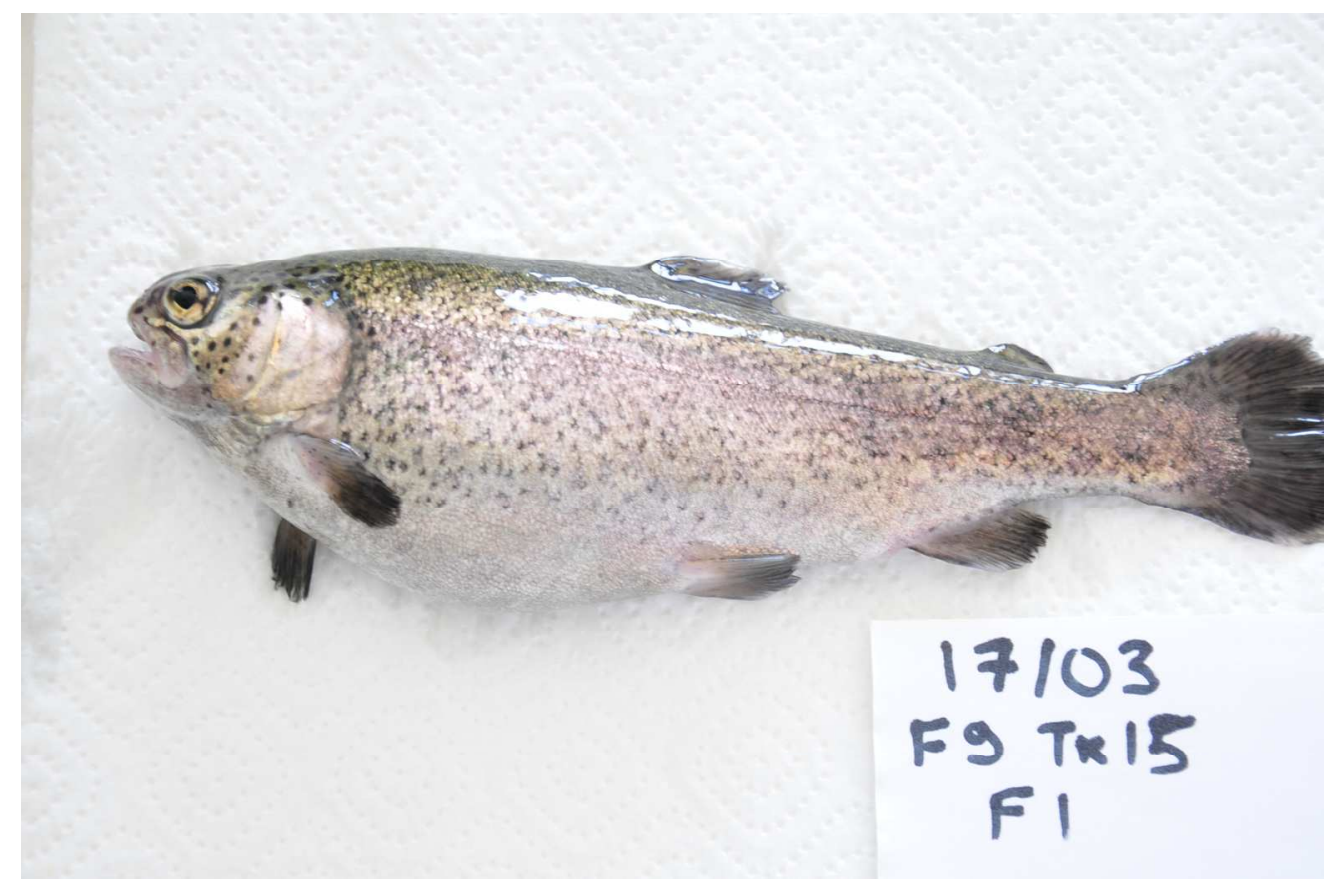

FIGURE 6. Abnormal body conformations, characterized by a fish length reduced in relation to its width. Observed in 15 fishes out of 60 fishes fed 2,745 $\pm 330 \mu \mathrm{gg}-1$ DON.

$181 \times 120 \mathrm{~mm}(300 \times 300 \mathrm{DPI})$ 


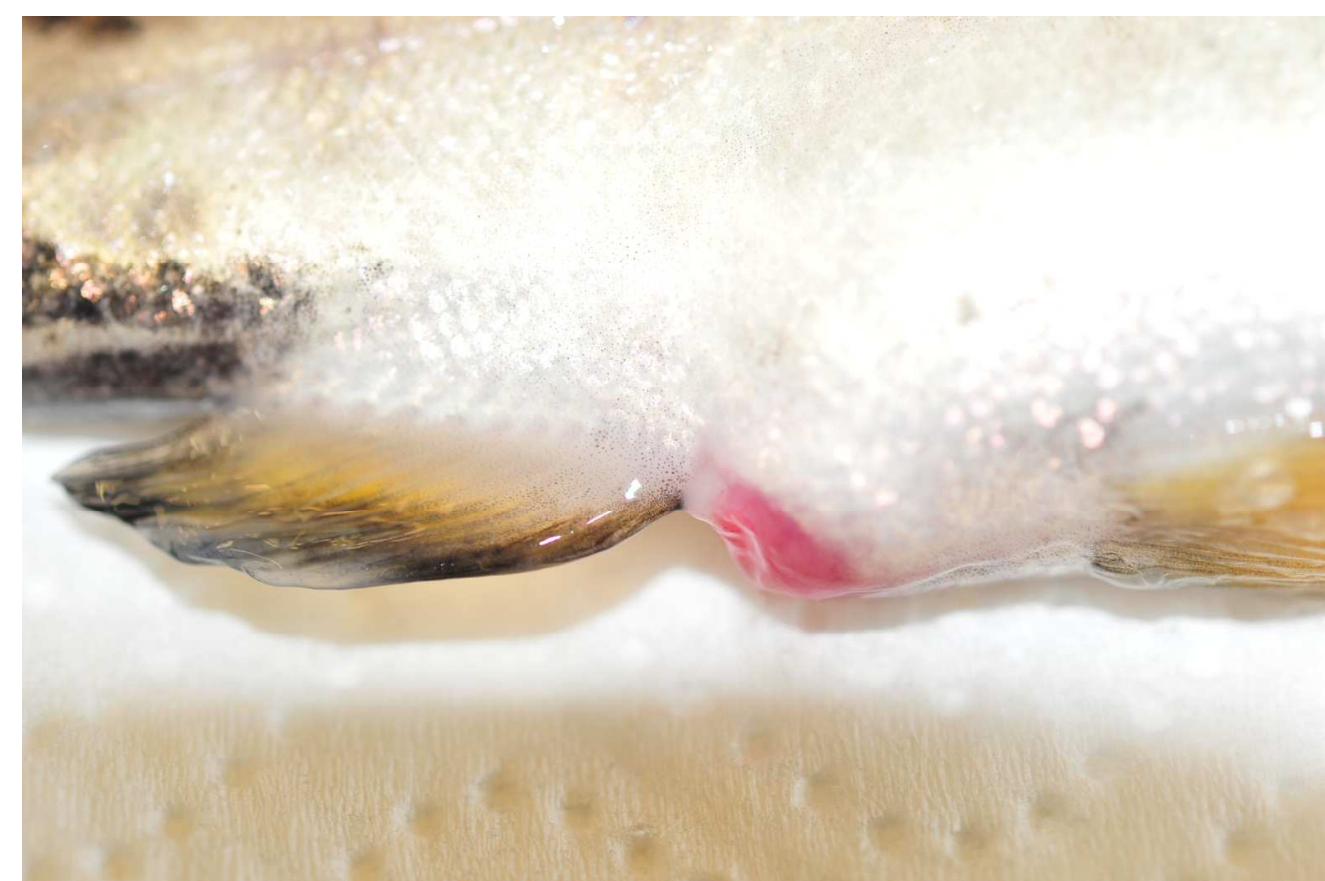

FIGURE 7. Fish presenting protruding anal papilla after being fed $2,745 \pm 330 \mu \mathrm{g}$ k-1 DON. Observed in 5 fishes out of 60 fishes fed 2,745 $\pm 330 \mu \mathrm{g} \mathrm{kg-1} \mathrm{DON}$.

$181 \times 120 \mathrm{~mm}(300 \times 300 \mathrm{DPI})$ 
TABLE 1: Experimental control diet ingredients and proximate composition.

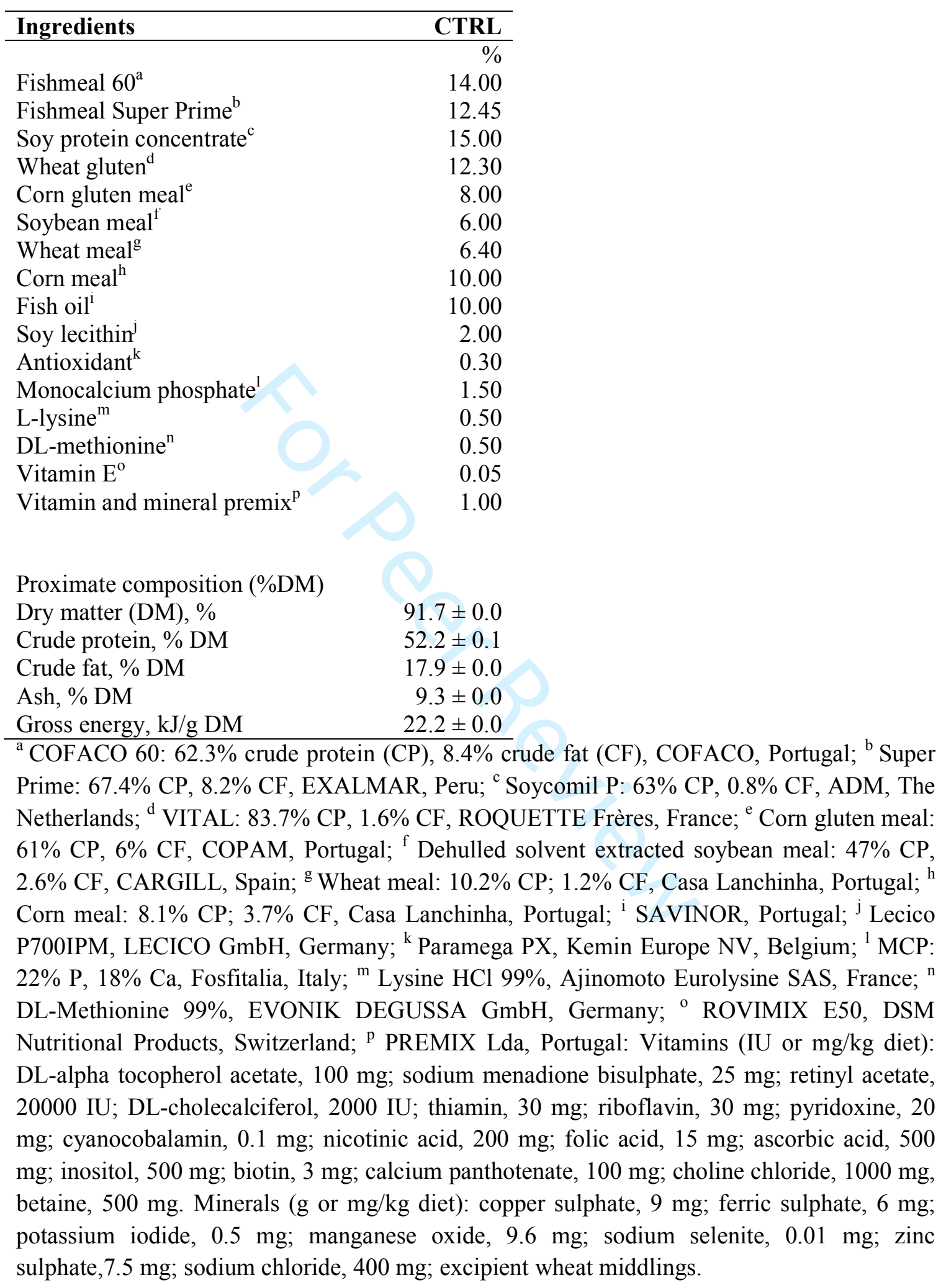


TABLE 2: Multi-mycotoxin analysis of experimental diets

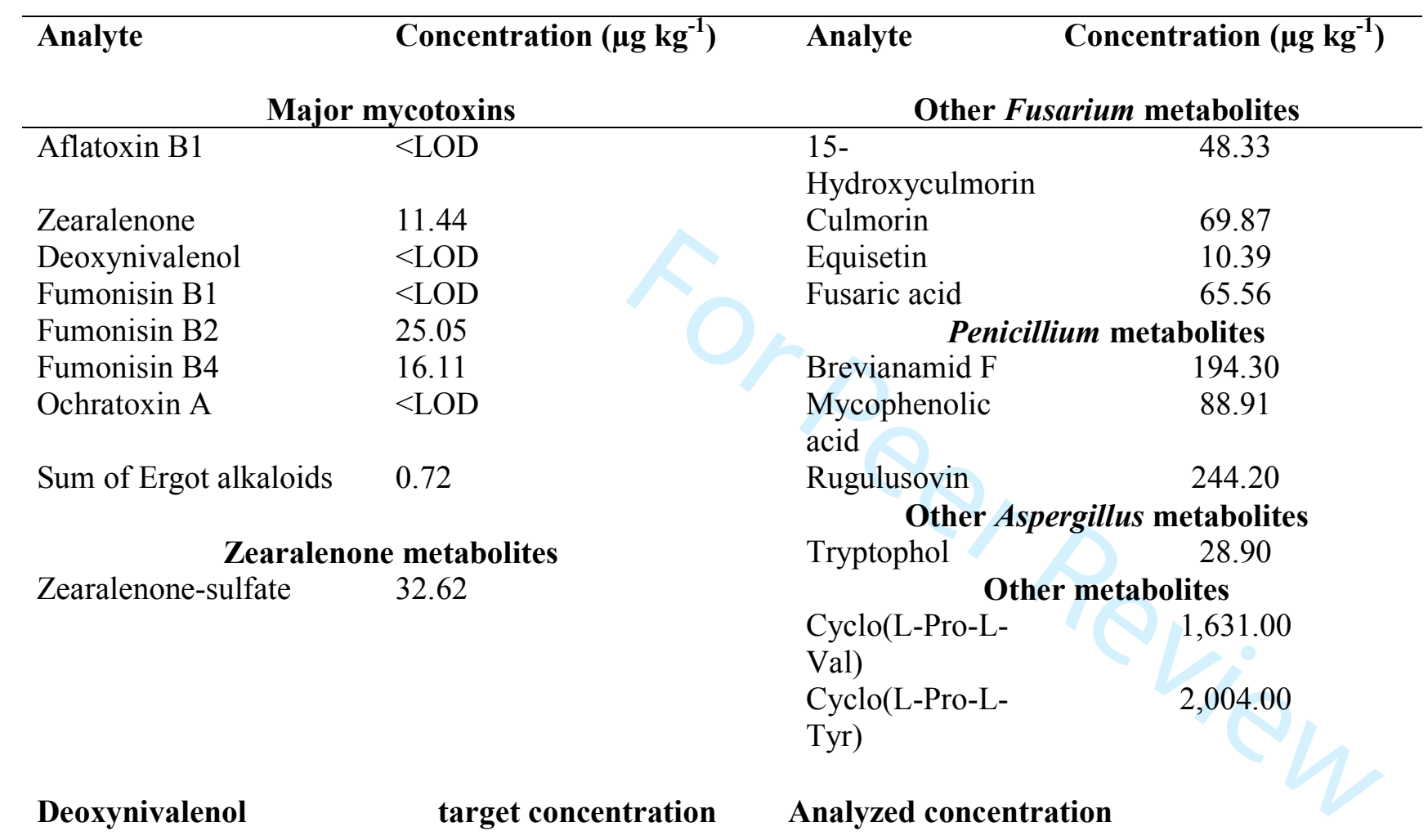

\begin{tabular}{lcc} 
CTRL & 0.0 & 0.0 \\
$1.1 \mathrm{DON}$ & 1,500 & $1,166 \pm 140$ \\
$2.7 \mathrm{DON}$ & 3,000 & $2,745 \pm 330$ \\
$0.3 \mathrm{DON}$ & 400 & $367 \pm 66.80$ \\
\hline
\end{tabular}

Limits of detection (LOD) for $\mathrm{AFB}_{1}=0.3 \mu \mathrm{g} \mathrm{kg}$. . For deoxynivalenol and ochratoxin A, detection limit are: 10, 50 and $0.2 \mu \mathrm{g} \mathrm{kg}-1$ and for fumonisin $\mathrm{B} 1$ the detection limit are $25 \mu \mathrm{g} \mathrm{kg}^{-1}$. Were analyzed 5 samples per diet. 
TABLE 3: Growth performance parameters determined in the short term/high DON dosage study.

\begin{tabular}{|c|c|c|c|c|c|c|c|c|c|c|c|c|c|c|c|}
\hline & Final Weight (g) & SGR $\left(\%\right.$ day $\left.^{-1}\right)$ & \multicolumn{2}{|r|}{ PER } & \multicolumn{2}{|c|}{ FI $\left(\mathrm{g} \mathrm{fish}^{-1}\right)$} & \multicolumn{3}{|c|}{ FCR } & \multicolumn{3}{|c|}{$\mathbf{C F}$} & \multicolumn{3}{|c|}{ TGC } \\
\hline CTRL & $101.36 \pm 19.81^{\mathrm{a}}$ & $2.52 \pm 0.07^{\mathrm{a}}$ & 2.17 & \pm 0.05 & 81.21 & $\pm 4.71^{\mathrm{a}}$ & 0.98 & \pm & 0.07 & 1.42 & \pm & $0.12^{\mathrm{ab}}$ & 0.113 & \pm & $0.005^{\mathrm{a}}$ \\
\hline $1.1 \mathrm{DON}$ & $95.37 \pm 19.20^{\mathrm{a}}$ & $2.46 \pm 0.06^{\mathrm{a}}$ & 2.01 & \pm 0.13 & 81.65 & $3.78^{\mathrm{a}}$ & 1.03 & \pm & 0.07 & 1.46 & \pm & $0.13^{\mathrm{b}}$ & 0.109 & \pm & $0.004^{\mathrm{a}}$ \\
\hline $2.7 \mathrm{DON}$ & $79.91 \pm 16.54^{b}$ & $2.20 \pm 0.09^{b}$ & 2.01 & \pm 0.07 & 64.03 & $\pm 2.87^{\mathrm{b}}$ & 1.05 & \pm & 0.04 & 1.39 & \pm & $0.12^{\mathrm{a}}$ & 0.094 & \pm & $0.005^{b}$ \\
\hline \multicolumn{16}{|c|}{ 1-way ANOVA } \\
\hline
\end{tabular}

Data are presented as mean \pm standard deviation. Values in the same column with different letters are significantly different $(\mathrm{P}<0.05) . \mathrm{NS}=$ not significant. $\mathrm{SGR}=$ Specific growth rate; $\mathrm{PER}=$ Protein efficiency rate; $\mathrm{FI}=$ Feed intake; $\mathrm{FCR}=$ Feed conversion ratio; $\mathrm{CF}=\mathrm{Condition}$ factor and TGC=thermal-unit growth coefficient. 


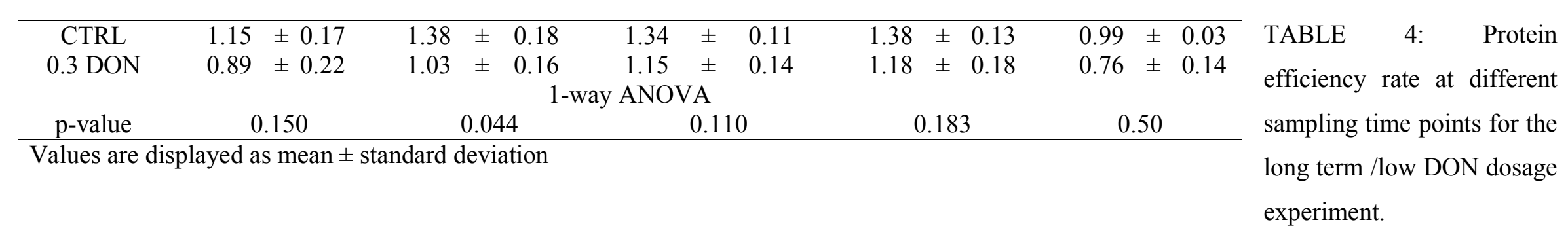


TABLE 5: Feed intake at different sampling time points for the long term /low DON dosage experiment.

\begin{tabular}{|c|c|c|c|c|c|c|c|c|}
\hline & Day 37 & & Day 62 & & Day 92 & & 125 & Day 168 \\
\hline CTRL & $1.92 \pm 0.06$ & 1.67 & \pm 0.08 & 1.61 & \pm 0.07 & 1.43 & \pm 0.09 & $1.41 \pm 0.03$ \\
\hline \multicolumn{9}{|c|}{ 1-way ANOVA } \\
\hline $\mathrm{p}$-value & 0.133 & & 0.041 & & 0.109 & & .189 & 0.070 \\
\hline
\end{tabular}

Values are displayed as mean \pm standard deviation 
TABLE 6: Effects of dietary treatments on LDH, ALT and AST activities in the serum for short term/high DON exposure experiment.

\begin{tabular}{|c|c|c|c|}
\hline & LDH $\left(\mathrm{IU} \mathrm{L}^{-1}\right)$ & $\operatorname{ALT}\left(\mathrm{IU} \mathrm{L}^{-1}\right)$ & $\operatorname{AST}\left(\mathrm{IU} \mathrm{L}^{-1}\right)$ \\
\hline CTRL & $1000.60 \pm 187.01^{\mathrm{a}}$ & $14.20 \pm 7.66^{\mathrm{a}}$ & $389.70 \pm 2.36^{\mathrm{a}}$ \\
\hline $1.1 \mathrm{DON}$ & $2001.18 \pm 825.06^{\mathrm{a}}$ & $22.00 \pm 0.97^{\mathrm{a}}$ & $543.80 \pm 45.68^{\mathrm{a}}$ \\
\hline $2.7 \mathrm{DON}$ & $1700.60 \pm 163.27^{\mathrm{a}}$ & $76.10 \pm 9.88^{b}$ & $876.50 \pm 87.60^{b}$ \\
\hline $\begin{array}{l}\text { 1-way ANOVA } \\
\text { p-value }\end{array}$ & 0.078 & $<0.001$ & $<0.001$ \\
\hline
\end{tabular}

Data are presented as mean \pm SD. Values in the same column with different letters are significantly different $(\mathrm{P}<0.05) . \mathrm{LDH}=$ Lactate Dehydrogenase; $\mathrm{ALT}=$ Alanine transaminase and $\mathrm{AST}=$ Aspartate Aminotransferase. $\left(\mathrm{IU} \mathrm{L}^{-1}\right)=$ International Units per liter. 
TABLE 7: Effects of dietary treatments on LDH, ALT, AST, ALP, Total protein and hematocrit in the serum at different sampling time points for long term/low DON exposure experiment.

\begin{tabular}{|c|c|c|c|c|c|c|c|}
\hline & Sampling & Hematocrit (\%) & $\operatorname{ALT}\left(\mathrm{IU} \mathrm{L} \mathrm{L}^{-1}\right)$ & AST $\left(\mathrm{IU} \mathrm{L} \mathrm{L}^{-1}\right)$ & LDH (IU L L $\left.{ }^{-1}\right)$ & $\operatorname{ALP}\left(I U L^{-1}\right)$ & T-Prot. $\left(\mathrm{g} \mathrm{L}^{-1}\right)$ \\
\hline & Initial & $51.2 \pm 0.08$ & $17.2 \pm 11.8$ & $432.9 \pm 157.2$ & $1846.5 \pm 1178.2$ & $*$ & $*$ \\
\hline CTRL & & $39.9 \pm 3.32$ & $11.1 \pm 3.5$ & $309.1 \pm 239.6$ & $1862.7 \pm 1199.4$ & $143.4 \pm 71.8$ & $3.0 \pm 0.67$ \\
\hline Mycotoxins & ays & $37.6 \pm 4.29$ & $24.4 \pm 25.4$ & $385.2 \pm 91.55$ & $2497.0 \pm 1573.1$ & $171.6 \pm 69.5$ & $3.0 \pm 0.5$ \\
\hline Control & & $*$ & & $324.7 \pm 144.4$ & $1968.7 \pm 1222.8$ & $154.4 \pm 47.72$ & $3.4 \pm 0.79$ \\
\hline Mycotoxins & 125 days & $*$ & & $216.5 \pm 97.3$ & $914.8 \pm 314.9$ & $146.3 \pm 69.11$ & $3.1 \pm 0.63$ \\
\hline
\end{tabular}

*Values could not be determined due to technical problems with samples. Values are displayed as averages \pm standard deviation. $\mathrm{N}=5$ per treatment. $\mathrm{LDH}=$ Lactate dehydrogenase; $\mathrm{ALT}=$ Alanine transaminase and AST $=$ Aspartate aminotransferase; ALP $=$ Alkaline phosphatase; $\mathrm{T}$ Prot. $=$ Total protein. $\mathrm{IU} \mathrm{L}^{-1}=$ International Units per liter. 


\section{Figure legend}

FIGURE 1: Growth curve representing the average weight of the fish during the long term experiment.

FIGURE 2: Feed conversion ratio at different sampling time points. Values are displayed as average \pm standard deviation.

FIGURE 3: Specific growth rate at different sampling time points. Values are displayed as average \pm standard deviation.

FIGURE 4. Onchorhynchus mykiss, histologic appearance of control (a) and 2.7 DON exposed fish (b); a. normal structure of hepatocytes; b. normal structure is disrupted, multiple hepatocytes are necrotic (star; observed in 1 out of 10 fishes sampled), scattered fibrin exudation (closed arrowhead; observed in 6 out of 10 fishes sampled), multiple hepatocytes show intracytoplasmatic eosinophilic, amorphous material (hyalinised hepatocytes) (open arrowheads; observed in 8 out of 10 fishes sampled), HE stain, bars $=50 \mu \mathrm{m}$; inlet: higher magnification showing hyalinised hepatocytes (open arrowheads).

FIGURE 5. Survival curve following infection with Yersinia ruckeri during the high dose experiment.

FIGURE 6. Abnormal body conformations, characterized by a fish length reduced in relation to its width. Observed in 15 fishes out of 60 fishes fed $2,745 \pm 330 \mu \mathrm{g} \mathrm{kg}^{-1} \mathrm{DON}$.

FIGURE 7. Fish presenting protruding anal papilla after being fed 2,745 $\pm 330 \mu \mathrm{g} \mathrm{kg}^{-1}$ DON. Observed in 5 fishes out of 60 fishes fed 2,745 \pm 330 $\mu \mathrm{g} \mathrm{kg}{ }^{-1} \mathrm{DON}$. 